\title{
An Investigation Of Selected Dimensions Of Retail Store Image: Bricks And Mortar Versus Online
}

\author{
Frank Wadsworth, (E-mail: fwadswo@ius.edu), Indiana University Southeast
} Eldon Little, Indiana University Southeast Jerry Wheat, Indiana University Southeast

Brenda Swartz, Indiana University Southeast

\begin{abstract}
Research examining the components of retail store image has focused on the most important features to customers. Merchandise return policy, an element of the Service dimension, has not been well researched. In the past decade the Internet has created another means to market products, and research relating to merchandise return policies for sales of Internet firms is virtually non-existent. This study compares the merchandise return policy in both "bricks and mortar" and Internet firms. Merchandise return policy appears to be a fertile area for future research.
\end{abstract}

\section{INTRODUCTION}

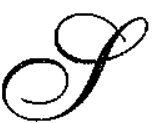

tore image studies generally require subjects to express their beliefs and ratings of various attributes of a store such as merchandise, service, clientele, and atmosphere which then serve as the basis of the store's image" (Wu and Petroshius, 1987). Over time nearly every component of retail store image has been meticulously studied, with much of the early research on retail store image dealing with identifying the components of store image and the relative importance of each variable. One area that has not been extensively studied is online store image or its components. Few studies have identified return policies as a component of store image.

In this paper, we will examine the components of store image and online store image, and report the results of an experiment on the impact of merchandise return policy on retail store image.

\section{BACKGROUND}

Retail store image has been dissected component by component and analyzed in past studies. Yet, to this day there is no one definitive answer to the question: "What component has the most impact on store image?" Marketers are willing to concede that a store's image is comprised of many components, not just one component. "Merchandise quality; styling; price; assortment; location; sales clerk service; general service; store environment; and pleasantness of shopping have been identified as components of store image" (Baker, Grewal, and Parasuraman, 1994; Mazursky and Jacoby, 1986; Lindquist, 1974). However, as studies have shown in the past, some components have more impact on store image than others. For example, James, Durand, and Dreves (1976) found that price and quality were more important than service and atmosphere. Studies have investigated numerous variables that might impact retail image. The most salient components of traditional bricks and mortar store image are: 1) atmosphere; 2) signage; 3) merchandise; and 4) service.

As shown in Table 1, a few studies have examined the components of online store image (Jang and Burns 2004; Chen and Lee 2005; and Elliot and Speck 2005). The most salient components of online store image are: 1) atmosphere; 2) merchandise; 3) service; and convenience. 
There are numerous articles that point out the growing interrelationships of bricks and mortar and online stores (Nasella 2000) and the need for better understanding of online retailing.

Table 1: Store Image Components

\begin{tabular}{|c|c|c|c|c|c|c|c|c|}
\hline & \multicolumn{5}{|c|}{ Bricks and Mortar Store Image } & \multicolumn{3}{|c|}{ Online Store Image } \\
\hline Item & $\begin{array}{c}\text { W/P/N } \\
2004\end{array}$ & $\begin{array}{c}\mathbf{M} / \mathbf{J} \\
1986\end{array}$ & $\begin{array}{c}\mathrm{L} \\
1974 / 5\end{array}$ & $\begin{array}{c}\mathrm{J} / \mathrm{D} / \mathrm{D} \\
1976\end{array}$ & $\begin{array}{c}\mathrm{C} / \mathrm{T} \\
2005\end{array}$ & $\begin{array}{c}\mathrm{J} / \mathrm{B} \\
2004\end{array}$ & $\begin{array}{c}\mathrm{C} / \mathrm{L} \\
2005\end{array}$ & $\begin{array}{c}\mathrm{E} / \mathrm{S} \\
2005\end{array}$ \\
\hline Atmosphere & & & & & & & & \\
\hline Store Atmosphere & $\bar{X}$ & & $\mathrm{X}$ & $\mathrm{X}$ & & & & \\
\hline Entertainment (atmosphere) & & & & & & & & $\mathrm{X}$ \\
\hline Is prestigious & $\mathrm{X}$ & & & & & & & \\
\hline Physical Facilities & & & $\mathrm{X}$ & & $\mathrm{X}$ & & & \\
\hline Store & & & & & & & $\mathrm{X}$ & \\
\hline Merchandise & & & & & & & & \\
\hline Merchandise & & & $\mathrm{X}$ & & & $\mathrm{X}$ & & \\
\hline Merchandise quality & $\mathrm{X}$ & $\mathrm{X}$ & & & & & & \\
\hline Merchandise pricing & & $\mathrm{X}$ & & & & & & \\
\hline Merchandise assortment & & $\bar{X}$ & & & & & & \\
\hline Assortment & & & & $\mathrm{X}$ & & & & \\
\hline Has well-known brand names & $\mathrm{X}$ & & & & & & & \\
\hline Price & & & & $\mathrm{X}$ & & & & \\
\hline Quality & & & & $\mathrm{x}$ & & & & \\
\hline Product Information (quantity and types of) & & & & & & & & $\mathrm{X}$ \\
\hline Information $\quad-\quad$ - & & & & & & & $\mathrm{X}$ & \\
\hline Service & & & & & & & & \\
\hline Service & & & $\mathrm{X}$ & $\mathrm{X}$ & $\mathrm{X}$ & $\mathrm{X}$ & $\mathrm{X}$ & \\
\hline Salesclerk service & & $\mathrm{X}$ & & & & & & \\
\hline Service, general & & $\mathrm{X}$ & & & & & & \\
\hline Institutional factor & & & $\mathrm{X}$ & & & & & \\
\hline Personnel & & & & $\mathrm{X}$ & & & & \\
\hline Store Activities & & & & & $\mathrm{X}$ & & & \\
\hline Post-Transaction factor & & & $\mathrm{X}$ & & & & & \\
\hline Trust (likeability and crediability) & & & & & & & & $\mathrm{X}$ \\
\hline Customer Support (guarantees) & & & & & & & & $\mathrm{X}$ \\
\hline Convenience & & & & & & & & \\
\hline Locational convenience & & $\mathrm{X}$ & & & & & & \\
\hline Convenience & & & $\mathrm{x}$ & & $\mathrm{x}$ & & $\mathrm{X}$ & \\
\hline Ease of Use (layout/ navigation) & & & & & & & & $\mathrm{X}$ \\
\hline Currency (up-to-date) & & & & & & & & $\mathrm{X}$ \\
\hline Miscellaneous & & & & & & & & \\
\hline Clientele & $\mathrm{x}$ & & $\mathrm{X}$ & & & & & \\
\hline Promotion & & & $X$ & & & $\mathrm{X}$ & $\mathrm{X}$ & \\
\hline Commodity & & & & & & & $X$ & \\
\hline
\end{tabular}

\section{Atmosphere}

"Store atmosphere is the combination of the store's physical characteristics, such as architecture, layout, signs and displays, colors, lighting, temperature, sounds, and smells, which together create an image in the customer's mind" (Levy and Weitz, 1998). The store atmosphere includes certain ambient factors. "Ambient factors are nonvisual, background conditions in the environment, including elements such as temperature, lighting, music, and scent" (Baker, Grewal, and Parasuraman, 1994; Yalch and Spangenberg, 1990; Milliman, 1986, 1982). 
"The store itself...can offer a unique atmosphere, or environment, that may influence the consumer's patronage decision" (Baker, Grewal, and Parasuraman, 1994; Kotler, 1973). Additionally, others have "...found that consumer's beliefs about the physical attractiveness of a store had a higher correlation with patronage intentions than did merchandise quality, general price level, or selection" (Baker, Grewal, and Parasuraman, 1994).

However, not all studies have found that that attempts to enhance the atmosphere in a store will yield benefits. Areni and Kim (1994) found that "...lighting does not significantly affect the amount of time spent in the store and the total purchases made." "...This result might be explained by the various goals that customers might have had upon entering the \{wine cellar" (Areni and Kim, 1994)."

Furthermore, "despite a widespread belief that store atmosphere has important effects on consumer behavior, there is very little systematic research on its effects (Areni and Kim, 1994)."

\section{Signage}

"Often retailers simply ask too much of a sign - more than any sign can deliver (Underhill, 1999)." Signs can display too much information, or not enough. "Given that a shopper's glance is fleeting, messages must be communicated clearly and quickly (Armata, 1996)." "Even as some opportunities for communication are being missed, many are being cluttered with so many messages that none stands out (Underhill, 1999)." "Signs and graphics...help customers find a department or merchandise, (Levy and Weitz, 1998)." "Graphics and Signage can \{also\} help maintain the customer's interest throughout the store," ("Enticing Shoppers," 1994). Maintaining the customer's interest keeps the customer in the store longer. "The amount of time shoppers spend in a store is perhaps the single-most important factor in determining how much they will buy," (Underhill, 1999). In other words, the longer the customer is in the store, the more he or she will purchase.

The "...comprising \{of\} graphics, signs, and theatrical effects both in the store and in windows - help boost sales by providing information on products and suggesting items or special purchases," (Levy and Weitz, 1998). "Signage, shelf position, display space and special fixtures all make it either likelier or less likely that a shopper will buy a particular item (or any item at all)," (Underhill, 1999).

\section{Merchandise}

"The retail store environment has a major influence on consumers' inferences about merchandise quality," (Baker, Grewal, and Parasuraman, 1994). For example, Mazursky and Jacoby (1986) found that "...the most heavily accessed cues for evaluating quality of merchandise were brand names, pictures of stores' interior design, merchandise material, and price ranges." "... [P]ictures of a store's interior were second only to brand name in being the most heavily accessed of several cues from which consumers could choose to evaluate merchandise quality," (Baker, Grewal, and Parasuraman, 1994; Mazursky and Jacoby, 1986). Additionally, others have "...suggested that store image may serve as a cue to the quality of a brand and vice versa," (Baker, Grewal, and Parasuraman, 1994). However, if the merchandise is not good quality, then nothing else matters.

"Today's customers are looking for a good value in what they purchase," (Levy and Weitz, 1998). "To some people, a good value means a low price," (Levy and Weitz, 1998). "Many different types of consumers have become much more price-sensitive," (Levy and Weitz, 1998). "Others are willing to pay more as long as they believe they're getting their money's worth in terms of product quality or service," (Levy and Weitz, 1998).

"Retailers have responded to their customers' needs with retail formats that emphasize low prices as a means of creating a differential advantage," (Levy and Weitz, 1998). "...TT]o compete with low prices, small retailers have developed niche strategies by providing a broader assortment of merchandise within a given product category and better service," (Levy and Weitz, 1998). However, "...many retailers...have successfully maintained their market appeal by offering customers high-quality merchandise and service without attempting to offer the lowest prices on a particular product category," (Levy and Weitz, 1998). 


\section{Service}

"There is ample evidence that the economic success of companies fluctuates with the quality of service that is offered," (Milbourn and Haight, 1998). "When service is poor, shoppers will find another store; bad service undoes good merchandise, prices, and location almost every time," (Underhill, 1999). "Research contained in a Harvard Business Review article found that high quality service is a dominant cause of repeat customers across industries," (Milbourn and Haight, 1998). Mazursky and Jacoby (1986) found that "the four most heavily accessed cues when forming quality of service impressions were the number of salespersons per department, number of cashiers per department, number of fitting rooms, and the merchandise return policy."

Few studies have focused on merchandise return policies as a component of store image. Return policies are a necessary evil that retail stores must brave. "Return policies are important because they insure customers against defective products, and risk-averse consumers are often willing to pay more to get a warranty or a return policy included as part of the terms of sale," (Mixon, 1999). "... [N]o [return policy] or an incomplete [return policy] may be a signal of low quality," (Mixon, 1999). Additionally, "return policies can function as an early warning system, alerting [companies] to problems within [its] organization," (Barsky, 1995). However, consumers' abuse of the return policy is an important consideration on the part of the retailers. "According to Ernst \& Young... a growing number of shoplifters are taking advantage of liberal return policies to elicit refunds for stolen merchandise," (Dacy, 1994).

Thirteen focus group sessions were conducted by the Reverse Logistics Executive Council and the University of Nevada's Center for Logistics Management, in which they found "...that companies with identical return policies can be viewed quite differently by consumers," ("Study of Store Returns," 2000). "This [finding led them] to believe what Matter[ed] more is the interface between the consumer and the retailer, not the actual return policy..." ("Study of Store Returns," 2000).

As a result of these and other studies, most marketers would agree that the consumer's image of a retail business is based on a variety of factors. A return policy alone will not enhance a store's image. In fact, the offering of certain services is an expected part of the retail mix in today's competitive retail environment. Most researchers would agree that these types of services are necessary, but not sufficient (also known as hygiene factors) to create a positive retail image. In other words, offering these services does not enhance a store's image, but failure to do so may cause damage.

"Today's consumer...uses the store's satisfaction guarantee as the best indicator of store reputation," (Beemer, 1997). However, "...many stores are... seeking ways to reduce the number of returns by limiting the store's satisfaction guarantee," (Beemer, 1997). According to a survey conducted by the Illinois Retail Merchants Association (IRMA) and Arthur Anderson \& Co., it was found that "... more than 95\% of retailers interviewed allow some form of returns," (Che, 1996; Hamilton, 1994). However, many of the return policies had limitations. For example, some offered cash refunds with a receipt, others only offered merchandise credit with a receipt, while others limited the return period (Che, 1996; Hamilton, 1994). When developing a return policy, "retailers are extremely challenged to find a [middle ground] between a return policy that the customer can live with and one the retailer can afford," (Hamilton, 1994).

"A too rigid return policy could cause a larger loss than it prevents..." (Parmley, 1988). For exampie, in today's market, customers expect a return policy, and if they don't get it they will shop somewhere else. "CEMA research found that nearly seven out of ten people say that a store's return policy is very important in their decision to shop there," (Pinkerton, 1997). A rigid return policy or no return policy could prove detrimental to the store's existence. Returns "... is a process that is generally considered to be an essential element of customer service and satisfaction," ("Return to Sender," 2000). "customer service is one of the biggest differentiators in business, and it is even more important on the Web," (Schultz, 2001). "Customer service is the most important factor - aleead of both price and on-time delivery - in determining whether a potential buyer returns to a particular merchant on the Web," (Bartholomew, 2001). 
Shopping online can provide limitless selection, convenience, speed, and information, perquisites that physical retail stores cannot offer (Underhill, 1999). Additionally, "m]any online businesses have more lenient return policies than do regular retailers, (Powell, 1998). "E-businesses should be cognizant of the fact [that] consumers are shopping for products they cannot touch or feel," (Savin and Silberg, 2000). "... [Thus, consumers] will seek insurance against an inappropriate fit, color, or pattern," (Padmanabhan and Prig, 1995). The bottom line is in order for online businesses to prosper, they need to be more flexible when it comes to returns.

"Today, about $58 \%$ of online retailers let customers return their purchases to brick-and-mortar stores according to a study...by Accenture, formerly Andersen Consulting" (Rosen, 2001). "Companies that create an effective Web presence can streamline operations, shorten response time to customer requests, gather more market data, increase their geographic reach, and ideally, sell more," (Savin and Silberg, 2000). However, "[i]t's...going to be tough for retailers to maintain a healthy store brand image while at the same time developing a healthy Internet brand image... While the former can help the latter, it could also work against them: if a retailer's Internet brand isn't well established, it could take away from a successful store image," (Kruger, 1999).

\section{OBJECTIVES}

The first objective of the study was to determine if the general components of store image were similar for bricks and mortar, and online stores. This objective could be accomplished by comparing factor analysis results of store image between online, and bricks and mortar stores.

Given the fact that few studies have focused on the component of return policies in the past, the second objective of this study attempts to analyze the impact of return policies on retail store image. Specifically, the following hypotheses were examined:

1) The stores exhibiting "satisfaction guaranteed" will receive higher ratings than the stores exhibiting "no merchandise returns" or than the stores exhibiting no stated return policy.

2) The online stores exhibiting "satisfaction guaranteed" will receive higher ratings than the stores exhibiting "no merchandise returns" or than the stores exhibiting no stated return policy.

3) The online stores will receive lower ratings than the retail stores.

\section{METHODOLGY}

The survey was developed after reviewing relevant literature revealing store image survey questions. The final survey instrument has 20 store image questions, one overall store rating question, and two demographic questions.

The experimental procedure involved three merchandise return policy treatments. One treatment displayed "satisfaction guaranteed," a second treatment displayed "no merchandise returns," and a third treatment, the control group, displayed no stated policy. The procedure also included two store type treatments, bricks and mortar, and online store. Subsequently, there are six experimental cells (three merchandise return policy's by two store types).

Subjects were 360 students from a small mid-western university. Each class was assigned to one of the six experimental cells and was shown 10 slides of either a bricks and mortar store or an online store. After the slide presentation, the subjects were given a questionnaire, comprised of twenty store image questions, and asked to fill it out regarding their attitudes about the store. To answer each store image question, subjects were given the following five options: 1) strongly agree, 2) agree, 3) neither agree nor disagree, 4) strongly disagree, and 5) disagree.

\section{DATA ANALYSIS}

Initial data analysis focused on determining the number of factors underlying store image. After determining store image dimensions, we continued by testing our hypotheses, and completed the data analysis step by using store image dimensions to explain overall store ratings. 


\section{Determining Store Image Dimensions}

Combined data from bricks and mortar, and online stores were examined using exploratory factor analysis. Factor Analysis results were tested for consistency by then separately examining store image dimensions for the two store types. Factor analysis using Principal Components and Maximum Likelihood extraction methods, Varimax, Quartimax, and Oblique rotations were used to examine the consistency of the factor analysis results. Factors loadings less than .33 are not listed in the factor analysis results.

Results of the combined survey data showed remarkable consistency across extraction methods and rotation techniques as shown in Table 2.

Table 2: Exploratory Factor Analysis Results by Extraction Method and Rotation Technique

\begin{tabular}{|c|c|c|c|c|c|c|}
\hline & & $\begin{array}{c}\text { Principal } \\
\text { Components } \\
\text { Extraction }\end{array}$ & & & $\begin{array}{l}\text { Maximum } \\
\text { Likelihood } \\
\text { Extraction }\end{array}$ & \\
\hline Item & $\begin{array}{l}\text { Varimax } \\
\text { Rotation }\end{array}$ & $\begin{array}{l}\text { Quartimx } \\
\text { Rotation }\end{array}$ & $\begin{array}{l}\text { Oblique } \\
\text { Rotation }\end{array}$ & $\begin{array}{l}\text { Varimax } \\
\text { Rotation }\end{array}$ & $\begin{array}{l}\text { Quartimx } \\
\text { Rotation }\end{array}$ & $\begin{array}{l}\text { Oblique } \\
\text { Rotation }\end{array}$ \\
\hline I feel comfortable shopping in this store & & & & & $.806 \mathrm{a}$ & $.692 \mathrm{a}$ \\
\hline This store has a pleasant atmosphere & & & $.555 \mathrm{c}$ & & $.718 \mathrm{a}$ & $.616 \mathrm{a}$ \\
\hline This store is well organized & & & $.555 \mathrm{c}$ & $.566 a$ & $.663 a$ & $.562 \mathrm{a}$ \\
\hline This store is convenient & $.670 \mathrm{~b}$ & $.661 \mathrm{~b}$ & $.703 \mathrm{c}$ & $.468 \mathrm{a}$ & $.436 \mathrm{a}$ & $.515 \mathrm{a}$ \\
\hline This store is not confusing & $.645 \mathrm{~b}$ & $.630 b$ & $.638 \mathrm{c}$ & $.490 \mathrm{a}$ & $.534 \mathrm{a}$ & $.502 \mathrm{a}$ \\
\hline This store is clean & $.643 \mathrm{~b}$ & $.652 \mathrm{~b}$ & $.649 \mathrm{c}$ & $.453 \mathrm{a}$ & $.466 \mathrm{a}$ & $.483 \mathrm{a}$ \\
\hline This store would be a pleasant place to shop & & & $.352 \mathrm{c}$ & $.413 \mathrm{a}$ & $.553 a$ & $.377 \mathrm{a}$ \\
\hline This store is appealing & & & & & $.817 \mathrm{a}$ & \\
\hline This store is attractive & & & & & $.781 \mathrm{a}$ & \\
\hline $\begin{array}{l}\text { This store provides knowledgeable sales } \\
\text { assistance }\end{array}$ & $.807 \mathrm{a}$ & $.820 \mathrm{a}$ & $.831 \mathrm{a}$ & $.879 \mathrm{~b}$ & & $.929 b$ \\
\hline The store has good service & $.759 a$ & $.777 \mathrm{a}$ & $.760 a$ & & & $.673 \mathrm{~b}$ \\
\hline The store provides helpful sales assistance & $.717 \mathrm{a}$ & $.728 \mathrm{a}$ & $.735 \mathrm{a}$ & $.662 b$ & & $.666 \mathrm{~b}$ \\
\hline The store's return policy is acceptable & $.602 \mathrm{a}$ & $.606 a$ & $.625 \mathrm{a}$ & $.403 \mathrm{~b}$ & $.419 \mathrm{a}$ & $.366 \mathrm{~b}$ \\
\hline This store has informative advertising & $.611 \mathrm{a}$ & $.640 \mathrm{a}$ & $.585 \mathrm{a}$ & & $.622 a$ & \\
\hline This store offers excellent value & $.572 \mathrm{a}$ & $.576 a$ & $.585 \mathrm{a}$ & & $.495 \mathrm{a}$ & \\
\hline The store attracts upper-class customers & $.794 \mathrm{c}$ & $.784 \mathrm{c}$ & $.814 \mathrm{~b}$ & $.780 \mathrm{c}$ & & $.783 \mathrm{c}$ \\
\hline The store is prestigious & & & $.744 \mathrm{~b}$ & $.711 \mathrm{c}$ & & $.692 \mathrm{c}$ \\
\hline The store has high quality products & $.553 c$ & $.546 \mathrm{c}$ & .5690 & $.436 \mathrm{c}$ & $.376 \mathrm{~b}$ & $.420 \mathrm{c}$ \\
\hline $\begin{array}{l}\text { The store has a limited selection of } \\
\text { products }\end{array}$ & $.459 c$ & & $.443 b$ & $.310 c$ & & \\
\hline & & & & & & \\
\hline Variance Explained & & $53.3 \%$ & & & $45.2 \%$ & \\
\hline
\end{tabular}

The first factor is labeled Atmosphere. Atmosphere includes items such as "I feel comfortable shopping in this store," "This store has a pleasant atmosphere," "This store is well organized," and "This store is convenient." The second factor, Service includes the items "This store provides knowledgeable sales assistance," "The store has good service," "The store provides helpful sales assistance," and "The store's return policy is acceptable." The third factor Store Prestige is comprised of "The store attract supper-class customers," "The store is prestigious," and "The store has high quality products." Coefficient Alpha scores for the three factors are $.801, .780$, and .716 respectively, all higher than Nunnally's (1978) threshold of .700 for construct dimensions (Table 3 ). 
Table 3: Reliability Results

\begin{tabular}{|l|l|c|}
\hline \multicolumn{1}{|c|}{ Factor } & \multicolumn{1}{|c|}{ Items } & \multicolumn{1}{c|}{ Coefficient Alpha } \\
\hline Service & The store provides knowledgeable sales assistance & .780 \\
\hline & The store has good service & \\
\hline & The store's return policy is acceptable & \\
\hline & The store does provide helpful sajes assistance. & \\
\hline Store Prestige & The store attracts upper-class customers & \\
\hline & The store is prestigious & \\
\hline & The store has high-quality products & \\
\hline & I feel comfortable shopping in this store & \\
\hline & This store has a pleasant atmosphere & \\
\hline & This store is well-organized & \\
\hline & This store is convenient & \\
\hline & This store is not confusing & \\
\hline & This store is clean & \\
\hline
\end{tabular}

Separate factor analyses for the Bricks and Mortar, and the Online stores were conducted to see if the results are similar to the combined survey data exploratory factor analysis. Results from the separate factor analyses are shown in Table 4.

Table 4: Exploratory Factor Analysis Results by Store Type, Extraction Method, and Rotation Technique

\begin{tabular}{|c|c|c|c|c|c|c|c|c|}
\hline & Bricks $^{1}$ & Bricks & Bricks & Bricks & Online & Online & Online & Online \\
\hline Item & $\mathrm{PC} \mathrm{V}$ & $\mathrm{PCO}$ & ML V & ML O & $\mathrm{PC} \mathrm{V}$ & $\mathrm{PC} \mathrm{O}$ & ML V & ML O \\
\hline I feel comfortable shopping in this store & $67 \mathrm{a}$ & $63 \mathrm{a}$ & $72 \mathrm{a}$ & $72 \mathrm{a}$ & & $61 \mathrm{c}$ & $.63 \mathrm{~b}$ & $66 \mathrm{a}$ \\
\hline This store has a pleasant atmosphere & & $.59 \mathrm{a}$ & & $.61 \mathrm{a}$ & $.77 \mathrm{~b}$ & $80 \mathrm{c}$ & $.52 b$ & $55 a$ \\
\hline This store is well organized & $.66 \mathrm{a}$ & $.65 a$ & $60 \mathrm{a}$ & $60 \mathrm{a}$ & $63 \mathrm{~b}$ & $62 \mathrm{c}$ & $48 \mathrm{~b}$ & $48 \mathrm{a}$ \\
\hline This store is convenient & $71 \mathrm{a}$ & $.73 \mathrm{a}$ & $62 a$ & $65 \mathrm{a}$ & $57 \mathrm{c}$ & $56 \mathrm{~b}$ & $43 \mathrm{c}$ & $41 \mathrm{c}$ \\
\hline This store is not confusing & $68 \mathrm{a}$ & $69 \mathrm{a}$ & $61 \mathrm{a}$ & $63 a$ & $40 \mathrm{~b}$ & & $40 \mathrm{c}$ & \\
\hline This store is clean & $68 \mathrm{a}$ & $.73 \mathrm{a}$ & $49 \mathrm{a}$ & $.53 \mathrm{a}$ & $.69 \mathrm{~b}$ & $77 \mathrm{c}$ & $48 \mathrm{c}$ & $40 \mathrm{c}$ \\
\hline This store would be a pleasant place to shop & $46 \mathrm{a}$ & $41 \mathrm{a}$ & $48 \mathrm{a}$ & $45 \mathrm{a}$ & $.56 \mathrm{c}$ & $.50 \mathrm{~b}$ & $.58 \mathrm{c}$ & $53 \mathrm{c}$ \\
\hline This store is appealing & & $48 \mathrm{~b}$ & & & & $.66 \mathrm{c}$ & $78 \mathrm{~b}$ & $83 \mathrm{a}$ \\
\hline This store is attractive & & $.51 \mathrm{~b}$ & & & $68 b$ & $65 \mathrm{c}$ & $67 \mathrm{~b}$ & $74 \mathrm{a}$ \\
\hline This store provides knowledgeable sales assistance & $86 \mathrm{c}$ & $90 \mathrm{c}$ & $96 \mathrm{c}$ & $1.01 \mathrm{c}$ & $.76 a$ & $.74 a$ & $78 \mathrm{a}$ & $.80 b$ \\
\hline The store has good service & $.78 \mathrm{c}$ & $76 \mathrm{c}$ & & $.68 \mathrm{c}$ & $.75 a$ & $73 \mathrm{a}$ & $71 \mathrm{a}$ & $.71 \mathrm{~b}$ \\
\hline The store provides helpful sales assistance & $76 \mathrm{c}$ & $78 \mathrm{c}$ & $.59 \mathrm{c}$ & $.58 \mathrm{c}$ & $.59 \mathrm{a}$ & $58 \mathrm{a}$ & $.59 \mathrm{a}$ & $.63 b$ \\
\hline The store's return policy is acceptable & & & & & $81 \mathrm{a}$ & $87 a$ & $66 a$ & $.68 \mathrm{~b}$ \\
\hline This store has informative advertising & $59 \mathrm{c}$ & $.56 \mathrm{c}$ & & & & $56 \mathrm{a}$ & & $.48 \mathrm{a}$ \\
\hline This store offers excellent value & & & & $48 \mathrm{a}$ & & & $.54 \mathrm{~b}$ & \\
\hline The store attracts upper-class customers & $85 \mathrm{~b}$ & $.86 b$ & $.85 b$ & $87 \mathrm{~b}$ & $.52 \mathrm{c}$ & $48 \mathrm{~b}$ & $45 \mathrm{c}$ & $42 \mathrm{c}$ \\
\hline The store is prestigious & $77 \mathrm{~b}$ & $.75 b$ & $.70 \mathrm{~b}$ & $68 \mathrm{~b}$ & $61 c$ & $.57 \mathrm{~b}$ & $.53 \mathrm{c}$ & $.49 \mathrm{c}$ \\
\hline The store has high quality products & $63 \mathrm{~b}$ & $.63 \mathrm{~b}$ & $49 \mathrm{~b}$ & $48 \mathrm{~b}$ & $.65 c$ & $66 b$ & $42 \mathrm{c}$ & $43 \mathrm{c}$ \\
\hline The store has a limited selection of products & & & & & $42 \mathrm{a}$ & $42 \mathrm{a}$ & & \\
\hline This store has well-known brand names & $.69 b$ & $.70 b$ & $60 \mathrm{~b}$ & $63 b$ & $60 \mathrm{a}$ & $62 \mathrm{a}$ & $47 \mathrm{a}$ & $45 \mathrm{~b}$ \\
\hline Variance Explained & $56.2 \%$ & & $49.3 \%$ & & $51.4 \%$ & & $42.9 \%$ & \\
\hline
\end{tabular}

Bricks = Bricks and Mortar store, PC V is Principal Components Extraction with Variamax Rotation, PC O is Principal Components Extraction with Oblique Rotation, ML V is Maximum Likelihood Extraction with Variamax Rotation, and ML O is Maximum Likelihood Extraction with Oblique Rotation.

For the bricks and mortar stores, the results are equivalent to the combined exploratory factor analysis results with the three factors of Atmosphere, Service, and Store Prestige. For the Online data, one of the three factors, Service is the same as the combined Service, and another factor (Store Quality) is similar to the combined survey data 
dimension of Store Prestige. The third factor, Atmosphere consists of items such as "This store is appealing," "This store is attractive," and "I feel comfortable shopping in this store."

Results from the three exploratory factor analyses show the factors underlying store image are Atmosphere, Service, and Store Prestige. These results are consistent with the literature on Store Image over the last 30 years. Data analysis will continue by testing the research hypotheses.

\section{Testing the Research Hypotheses}

The research hypotheses suggested that merchandise return policy and store type influence consumers' store image perceptions. This section will examine the influence of store return policy first and then the effect of store type on consumer perceptions.

One-Way Analysis of Variance for each of the 20 store image items tested the first research hypothesis. The first hypothesis stated that satisfaction guaranteed return policy stores will be more positively evaluated than no stated return policy stores which will be more positively rated than stores with no merchandise return policy.

Results are show in Table 5, and the hypotheses suggest that Satisfaction Guaranteed stores would be rated A, No Stated Policy stores would be rated B, and No Merchandise Return Policy stores would be rated C.

Table 5: Store Image Item Statistically Significant Hypothesis 1 Tests

\begin{tabular}{|l|c|c|c|}
\hline \multicolumn{1}{|c|}{ Item } & Satisfaction Guaranteed & No Stated Policy & No Merchandise Return Policy \\
\hline This store has a pleasant atmosphere & $\mathrm{B}$ & $\mathrm{A}$ & $\mathrm{B}$ \\
\hline The store is attractive & $\mathrm{B}$ & $\mathrm{A}$ & $\mathrm{A}$ \\
\hline This store has well-known brand names & $\mathrm{B}$ & $\mathrm{B}$ & $\mathrm{B}$ \\
\hline The store's return policy is acceptable & $\mathrm{A}$ & $\mathrm{A}$ & $\mathrm{A}$ \\
\hline This store offers excellent value & $\mathrm{B}$ & $\mathrm{A}$ & \\
\hline
\end{tabular}

For the item, "This store has a pleasant atmosphere," stores not stating their return policy are viewed as having a more pleasant atmosphere than no return and satisfaction guaranteed stores. For the item "The store is attractive," stores not stating their return policy are viewed as being more attractive than satisfaction guaranteed stores. For the item "The store has well-known brand names," stores having a no return policy are seen as having more well-known brand names than no stated policy and satisfaction guaranteed stores.

For the item "The store's return policy is acceptable," stores not stating their return policy and satisfaction guaranteed stores are perceived as having more acceptable return policies than stores having a no return policy. For the item "This store offers excellent value," stores having a no return policy and not stating a return policy are seen as offering a better value than stores offering a satisfaction guaranteed policy. Satisfaction Guaranteed store respondents are about four years older than respondents evaluating the no stated policy and no return policy stores. The statistical tests do not offer support for the first hypothesis.

One-Way Analysis of Variance for each of the 20 store image items tested the second research hypothesis. The second hypothesis stated that bricks and mortar stores will be more positively evaluated than Internet stores. Results are show in Table 6.

For the item, "This store is clean," B\&M stores are seen as being cleaner than Internet stores. For the item, "The store is attractive," Internet stores are perceived as more attractive than B\&M stores. For the item, "The store has good service," Internet stores are seen as offering better service than B\&M stores.

For the item, "The store has informative advertising," Internet stores are seen as having more informative advertising than B\&M stores. For the item, "The store is convenient," B\&M stores are seen as less convenient than 
Internet stores. For the item, "This store offers excellent value," Internet stores are perceived as offering better value than B\&M stores. For the item, "This store is confusing," B\&M stores are seen as more confusing than Internet stores.

Table 6: Store Type Statistically Significant Hypothesis 2 Tests

\begin{tabular}{|l|c|c|}
\hline \multicolumn{1}{|c|}{ Item } & Bricks and Mortar & Online \\
\hline This store is clean & A & B \\
\hline The store is attractive & B & A \\
\hline The store has good service & B & A \\
\hline The store has informative advertising & $\mathrm{B}$ & $\mathrm{A}$ \\
\hline The store is convenient & $\mathrm{B}$ & $\mathrm{A}$ \\
\hline This store offers excellent value & $\mathrm{B}$ & $\mathrm{A}$ \\
\hline This store is confusing & $\mathrm{B}$ & $\mathrm{A}$ \\
\hline
\end{tabular}

Only one statistical test supports the second hypothesis, the test for the perception of cleanliness between the two store types.

The last statistical technique in the data analysis step is to determine if store image factors can explain overall store rating. Using multiple regression we are able to explain $44.8 \%$ of the variation in overall store ratings with the three store image dimensions. Every one of the store image dimensions is a statistically significant predictor of overall store ratings (Table 7).

Even though the research hypotheses were not supported by the survey data, overall store image is explained by the three store image dimensions of Shopping Comfort, Sales Assistance, and Store Prestige.

Table 7: Multiple Regression Results

\begin{tabular}{|l|c|c|c|c|}
\hline \multicolumn{1}{|c|}{ Dimension } & $\begin{array}{c}\text { Unstandardized Regression } \\
\text { Coefficient }\end{array}$ & Standard Error & T - Statistic & Significance \\
\hline Constant & .034 & .213 & 0.160 & .873 \\
\hline Shopping Comfort & .407 & .053 & 7.737 & .000 \\
\hline Sales Assistance & .167 & .049 & 3.410 & .001 \\
\hline Store Prestige & .196 & .046 & 4.268 & .000 \\
\hline
\end{tabular}

\section{CONCLUSIONS}

The study further confirmed that the dimensions of retail store image are fundamentally the dame for "Bricks and Mortar" and Online retail stores. On the other hand, the study was inconclusive as to the impact of return policy on store image for both "Bricks and Mortar" and Online retailers.

\section{REFERENCES}

1. Areni, C.S. and D. Kim (1994), The Effects of In-Store Lighting on Browsing, Stores, Vol. 76, No. 8, RR7RR8.

2. Armata, K. (1996), Signs that Sell, Progressive Grocer, Vol. 75, No. 10, 21.

3. Baker, J., D. Grewal, and A. Parasuraman (1994), The Influence of Store Environment on Quality Inference and Store Image, Journal of the Acadeny of Marketing Science, Vol. 22, No. 4, pp 328-330, 332.

4. Barsky, J. (1995), Guarantee; Warranty, Loyalty, American Demographics, September, 72-74.

5. Bartholomew, D. (2001), Service to Order, (Article 11), Marketing 01/02, 23 ${ }^{\text {rd }}$ ed., McGraw-Hill/Dushkin: Guilford, Connecticut, 62-64. 
6. Beemer, B. (1997), It's Guaranteed: Consumers Care about Reputation, Discount Store News, Vol. 36, No. $7,16$.

7. Chang, Chih-Hon and Chia-Yu Tu, (2005), Exploring Store Image, Customer Satisfaction and Customer Loyalty Relationship: Evidence from Taiwanese Hypermarket Industry, Journal of American Academy of Business, Vol. 7, No. 2, 197-202.

8. Che, Y. (1996), Customer Return Policies for Experience Goods, The Journal of Industrial Economics, Vol. 44, No. $1,17-24$.

9. Chen, Wen-Jung and Chuan Lee (2005), The Impact of Web Site Image and Consumer Personality on Consumer Behavior, International Journal of Management, Vol. 22, No. 3, 484-498.

10. Dacy, J., II (1994), When Shoplifters ask for Refunds, Nation's Business, Vol. 82, No. 2, 27.

11. Elliot, Michael T, and Paul Surgi Speck (2005), Factors That Affect Attitude Toward A Retail Web Site, Journal of Marketing Theory and Practice, Vol. 13, No. 1, 40-52.

12. Enticing Shopper to Follow the Yellow brick Road, (1994), Chain Store Age Executive Shopping Center Age, Vol. 70 , No. 8, 60-61.

13. Hamilton, S.S. (1994), Return to Seller, Sales and Marketing Management, Vol. 146, No. 8, 21.

14. James, D.C., R.C. Durant, and R.A. Dreves (1976), The Use of Multi-Attribute Attitude Models in a Store Image Study, Journal of Retailing, Vol. 56, Summer, 23.

15. Jang, Eunyoung, and, Leslie Davis Burns (2004), Components of Apparel Retailing Web Sites, Journal of Fashion Marketing and Management, Vol 6., No. 4, 375-388.

16. Kotler, Phillip (1973), Atmospherics as a Marketing Tool, Journal of Retailing, Vol. 49, Winter, 40-64.

17. Kruger, R.M. (1999) Click and Mortar, Discount Merchandiser, Vol. 39, No. 10, 25-36

18. Levy, M. and B.A. Weitz (1998), Retailing Management (Third Edition), Irwin/McGraw-Hill, 474, 563.

19. Lindquist, Jay D. (1974), Meaning of Image, Journal of Retailing, Vol. 50, No. 4, 29-38, 116.

20. Mazursky, D. and J. Jacoby (1986), Exploring the Development of Store Images, Journal of Retailing, Vol. 62, No. 2 Summer, 145-165.

21. Milbourn, G., Jr. and G.T. Haight (2001), A Primer on Quality Service, Marketing 01/02, 23 ${ }^{\text {rd }}$ ed., McGrawHill/Dushkin, Guilford, Connecticut, 58-59.

22. Milliman, Ronald E. (1982), The Effects of Background Music Upon the Shopping Behavior of Supermarket Patrons, Journal of Marketing, Vol. 46, No. 3, 86-91.

23. (1986), The Influence of Background Music on The Behavior of Restaurant Patrons, Journal of Consumer Research, Vol. 13, No. 2, 286-288.

24. Mixon, F.G., Jr. (1999), Customer Return Policies for Experience goods: The Impact of Product, Price and Consumer Search Cost on Seller-Provided Information Cues, Applied Economics, Vol, 31, No. 3 March, 331336.

25. Nasella, Henry (2000), The Second Dot-coming: Brick-and-Mortars Must Move Online, Direct Marketing, Vol. 63, No. 5, 34-37.

26. Nunnally, Jum C. (1978), Psychometric Theory, New York : McGraw-Hill.

27. Padmanabhan, V. and I.P.L. Pug (1995), Returns Policies: Make Money by Making Good, Sloan Management Review, Vol. 37, No. 1 Fall, 65-72.

28. Parmley, J.K. (1988), The Risky R's of Retailing, Security Management, Vol. 32, No. 10, 31-33.

29. Pinkerton, J. (1997), Getting Religion about Returns, Dealerscope Consumer Electronics Marketplace, Vol. 39 , No. 11, 19.

30. Powell, E. (1998), Electronic Commerce: Web-Based Businesses are Booming, Office Systems, Vol. 15, No. 9, 12-15.

31. Retum to Sender, (2000), Modern Materials Handling, Vol. 55, No. 6 Mid-May, 64-65.

32. Rosen, C. (2001), Ready for the Returns Informationweek, No 819 January, 22-24.

33. Savin, J. and D. Silberg (2000), There's more to E-Business than Point and Click, The Joumal of Business Strategy, Vol. 21, No. 5 October, 11-13.

34. Schultz, K., E-Commerce Tools - Picks, Clicks, and Shopping Carts - Our First E-Commerce Lab Test looks at Three Products Ready to Help you make the Brick-to-Click Conversion, (2001), Internetweek, No 857, 2326.

35. Study of Store Returns Yields useful Information for Retailers, (2000), DSN Retailing Today, Vol. 39, No. 20 October, 20. 
36. Underhill, P. (1999), Why We Buy, Simon \& Schuster, New York, New York, 32-33, 72-73, 160, 215-126.

37. Yalch, Richard and Spangenberg, Eric (1990), Effects of Store Music on Shopping Behavior, Journal of Consumer Marketing, Vol. 7, No. 2, 55-64.

38. Wu, B.T.W. and S.M. Petroshius (1997), The Halo Effect in Store Image Measurement, Journal of the Academy of Marketing Science, Vol. 15, No. 3, 44-51.

39. Wu, B.T.W., Susan Petroshius, and Stephen Newell (2004), The Impact of Store Image, Frequency of Discount, and Discount Magnitude on Consumers' Value Perceptions and Search Intention, Marketing Management Journal, Vol. 14, No. 1, 14-22.

NOTES 
NOTES 